liberties than perhaps he properly deserves, particularly in light of the clandestine manner in which he conducts his affairs and the farreaching consequences of his activities.

Interestingly, in the United States, the American Bar Association has expressly included provision for lawyer/lobbyists in its Canon of Professional Ethics. In particular, Canon 26 states as follows: ${ }^{35}$

A lawyer openly, and in his true character may render professional services before legislative or other bodies, regarding proposed legislation, and in advocacy of claims before departments of government, upon the same principles of ethics which justify his appearance before the Courts; but it is unprofessional for a lawyer so engaged to conceal his attorneyship, or to employ secret personal solicitations, or to use means other than those addressed to the reason and understanding, to influence action.

Lawyer/lobbyists are not ordinary lawyers. Nor, however, are they particularly unique. They are neither flamboyant nor dramatic, unless of course one finds drama in cleverness and subtlety. They are not generally known to the public, nor are they known to a good proportion of their own profession. Not unlike many lawyers, they are wellrespected by the business community, have the right contacts in high places, possess superior intellectual capacity, and are well remunerated. They do not necessarily specialize in any particular area of the law, although many do. Ultimately, their specialty is the art of influence, but then the art of influence is a talent that many lawyers share. What does set apart the lawyer/lobbyists is their ability to alter the course of legislative history through no less than a skilful manipulation of the decision-making process. ${ }^{36}$ For this reason alone, the lawyer as lobbyist should not be regarded casually.

the above canon. Moreover, many provincial law societies are considering the adoption of the C.B.A. Code of Professional Conduct as part of the formal rules governing the conduct of lawyers within their respective jurisdictions.

35 For a review of the lawyer as lobbyist from an American point of view, reference may be made to the following articles: Hoffman, Lawyer as a Lobbyist, (1963) University of Illinois Law Forum 16; Satter, The Lawyer as a Legislative Lobbyist, (1960) 34 Connecticut Bar Journal 38; Crow, Considerations of the Compatibility of Legal Standards of Ethics and Lobbying Activity, (1966) 18 Alabama Law Review 425; and Hakman, Lobbying the Supreme Court-An Appraisal of "Political Science Folklore". (1966) 35 Fordham Law Review 15.

36 Probably, the most recent example in Canada of the lawyer as lobbyist surfaced in Ontario with the throwaway soft drink container issue. See the Globe and Mail, dated Feb. 28, 1977.

- B.A., LL.B., Member of Ontario Bar, Assistant Professor, Faculty of Law, University of Alberta.

\title{
THE ENVIRONMENT AND THE LAW IN CANADA'S NORTH
}

As the capital of the Northwest Territories, Yellowknife, enters its second annual arsenic scare, it is an understatement to say that the environment generally and the delicate ecological balance of the Arctic have attracted wide public attention.

With the pressure in recent years to explore for oil and gas in the Arctic, legislation and its enforcement by both the Federal and Territorial Governments has received top priority. By way of example, yet not intending to produce an exhaustive list, the Fisheries Act, the Territorial Land Use Regulations ${ }^{1}$ passed pursuant to the Territorial Lands Act, the Northern Inland Waters Act, the Arctic Waters Prevention Pollution Act and the Clean Air Act are all Federal

\footnotetext{
1 These Regulations are dated 2 November, 1971, SOR/71-580 by P.C. 1971-2287.
} 
legislation dealing solely with the environment. The Territorial Government has also been busy enacting legislation respecting the safe operation of mines, the use of explosives and pesticides.

Impetus has been added through the hearings recently concluded by Mr. Justice Berger, as Commissioner of the Mackenzie Valley Pipeline Inquiry, concerned as he has been with the social, economic and environmental impact on the Northwest Territories of such a project. The National Energy Board, too, has held hearings in both Territories and elsewhere in Canada, and as at the writing hereof, continues to do so concerning the necessity of a Mackenzie Valley gas pipeline.

Since 1971, there have been a number of companies prosecuted mainly under the Fisheries Act or the Territorial Lands Act, the latter for breaches of certain conditions imposed under permits issued pursuant to the Land Use Regulations. There have been various defences advanced by these companies, but for the most part, they have been unsuccessful. Though some of these decisions have been reported, most are unreported, hence are unavailable through normal research to the legal profession.

The purpose of this paper, therefore, is to provide to the profession a review of those cases decided in the Yukon and Northwest Territories since 1971 in the area of environmental law, outlining some of the defences attempted, one at least that has not been attempted yet may be available, and covering the principles of sentencing of companies convicted of contravening pollution control legislation covering a number of days where heavy fines of a maximum of $\$ 5,000.00$ per day are authorized. The format will be to deal with these three subjects in converse order.

\section{Principles of Sentencing}

So that there be no misunderstanding, this examination is restricted to the principles that have been enunciated by courts in the sentencing of large and small companies, not the sentencing of people.

The first case would appear to be the case of $R$. v. Pat McNulty Limited ${ }^{2}$ which involved two counts laid against the defendant company under the Explosives Act, being Chapter 102 of the Revised Statutes of Canada, 1952, respecting the illegal storage of explosives. In March of 1971, at Fort Good Hope, the learned Chief Magistrate levied fines of $\$ 25.00$ on Count 1 and $\$ 50.00$ on Count 2. The Crown appealed these fines on the basis that they were too lenient and inadequate and out of proportion to the severity of the penalty provided by the law, among other grounds. The sentence appeal went before Morrow J. (as he then was) of the Territorial Court, who increased the fines to $\$ 300.00$ on Count 1 and $\$ 100.00$ on Count 2. In passing sentence, His Lordship felt obliged to make the following comment:

It seems to me we are hearing a lot from the press and newspapers and television and so on about the ecology of the North and all that type of thing, and how it must be protected, and yet despite that, it seems to me as I travel around the country, the corporations from Eastern Canada and the United States show almost total disregard of the situation. They almost show contempt for the country, as if they think we are still a wild wilderness with aborigines wandering around from camp to camp, with the way they handle it.

In 1973 , the first case was brought to court charging a company for a 
breach of the Territorial Land Use Regulations. The charge was under $\mathrm{s}$. 3.3(1) of the Territorial Lands Act, alleging a breach of $s .17(1)$ of the Territorial Land Use Regulations, which Regulation requires a Land Use Permit in a land management zone when a land use operation is being conducted. Kenaston Drilling (Arctic) Ltd. had apparently been detected operating a Nodwell vehicle across the tundra 65 miles north of Inuvik without a Land Use Permit. The maximum fine provided in the legislation was $\$ 5,000.00$ per day. On appearance before a lay justice of the peace in Inuvik, the defendant company was fined $\$ 100.00$ and $\$ 4.00$ costs. The Crown took a sentence appeal to the Supreme Court of the Northwest Territories, whereupon the appeal was allowed and the fine increased to $\$ 2,000.00$. This case is reported $R$. v. Kenaston Drilling (Arctic) Ltd. ${ }^{3}$ At page 386, Morrow J. reasoned as follows:

Counsel have been unable to cite any reported cases that can be said to bear directly on the subject.

I am not unaware of the general principles that should be considered in sentencing for the commission of a crime. It is my opinion that offences such as is provided for in the present legislation require perhaps a special approach. I would be remiss as a judge in this territory if I did not take notice of the need and purpose of the present legislation, to protect the "control and use of the surface of the land," a land which although tundra in nature and frozen over for many months each year is none the less a delicate land, easily damaged and perhaps when once damaged impossible to repair. This is without any mention of the possible use that our original inhabitants, in this case, Eskimos, may still be making of it and how their way of life may be still dependent on its being preserved in its natural state. It may very well be that in the present case no actual damage took place. But surely the test to apply in approaching the question of sentence should be less a concern of what the damage was but more a concern of what the damage might have been.

In cases of this kind to fine a corporation such as the present one a mere $\$ 100$ is to in effect invite breaches, to invite the gamble. Where the economic rewards are big enough persons or corporations will only be encouraged to take what might be termed a calculated risk. It seems to me that the courts should deal with this type of offence with resolution, should stress the deterrent, viz., the high cost, in the hope that the chance will not be taken because it is too costly. (emphasis added)

It should also be pointed out that counsel for the company drew attention to the fact that the respondent "was a small local company with a record of being a good citizen in the community".

Then, in 1973 and 1974, charges under the Territorial Lands Act for breaches of Land Use Permit conditions were laid against Panarctic Oils Ltd. and against Elf Oil Exploration and Production Canada Ltd. ${ }^{4}$ for a breach of the Fisheries Act. These three cases are all important because of the penalties awarded, bearing in mind that the maximum fine for each day an offence continues, whether under the Territorial Land Act or the Fisheries Act is $\$ 5,000.00$. The fines levied were $\$ 3,000.00$ against Panarctic, $\$ 2,500.00$ against Gulf and $\$ 2,000.00$ against Elf.

In the Panarctic case, that company obtained a Land Use Permit covering their drilling operations conducted on their Gemini E-10 well site located on Ellesmere Island in the High Arctic. The original intent was to drill the well to 10,000 feet and a sump was designed to hold drilling mud for a well drilled to that depth. The drilling, however, continued to 12,614 feet. When the drilling was completed and the drilling mud tanks and warm water tanks emptied into the sump an overflow from the sump occurred, likely due to the warm water melting

${ }^{3}$ (1973) 12 C.C.C. (2d) 383.

- These three cases are all unreported. 
part of the sump wall. The charge was that the company breached one of the conditions of their Land Use Permit, namely Condition 20, which required that "Sumps must be constructed of a sufficient size so as to contain all drilling fluid and mud".

Between the date of the overflow and the trial, Panarctic retained independent environmental consultants to do an on-site inspection and an overview assessment of the environmental implications of the disturbance. The report which was presented to the court by counsel for the company indicated that the flows of drilling mud, although esthetically displeasing, caused a minimal disturbance to vegetation and consequently to wild life habitat. The report went on to say that "damage to aquatic life is expected to involve only minor vertebrates" and "the material is not toxic to plants". The report concluded with the comment "the overall environmental concern at the site is esthetics".

In view of the foregoing, the court felt that in the circumstances, an appropriate fine would be $\$ 3,000.00$.

The Gulf case was a similar case dealing with their Gulf mobile Parsons N-10 drilling rig located near Parsons Lake in the Northwest Territories. In that case, their sump sprung a leak causing some drilling mud and fluids to run into a very small pond which contained no fish or other aquatic life. Again, because of the lack of any real environmental damage, the court felt that an appropriate fine should be $\$ 2,500.00$.

The Elf case was slightly different in that it involved a charge under the Fisheries Act, particularly 8. 33(2) and alleged that Elf did unlawfully permit the deposit of a deleterious substance at a place where it did enter water frequented by fish. The facts are that Elf located on a point of land in the Kugaluk Estuary on the bank of the Kugaluk River in the Mackenzie Delta, a fuel storage site consisting of three 10,000 gallon diesel fuel bladders and one 20,000 gallon gasoline bladder. As a land use inspector overflew the site, he observed on the water of the Kugaluk Estuary what he took to be an oil slick. An examination of the fuel storage site showed that one of the 10,000 gallon bladders holding diesel fuel was leaking at the base of the valve stem where it had previously been patched. The fuel which had escaped seeped through the sand and entered the water of the Kugaluk Estuary. It was admitted that the diesel fuel was a deleterious substance and further that the waters of the Kugaluk Estuary were waters frequented by fish.

At the trial, the company entered a plea of not guilty based on the defence which arises from s. 32(8) of the Fisheries Act, which will be dealt with later in this paper. Notwithstanding that defence, however, the company was convicted by the learned magistrate who fined the company $\$ 2,000.00$. In considering the appropriateness of that fine, what obviously counted with the learned magistrate was the prompt action of the company in getting immediately into the area and engaging in a program which involved the stopping of the leak from the fuel bladder, the building of dikes, the replacement of the bladder, the transfer of the fuel from the faulty bladder to the new bladder, the recovery of oil from the sand and the burning of it, as well as the installation of a river boom to contain the spread of oil. The cost to the company was approximately $\$ 30,000.00$.

Then, in 1975, there was the case of $R$. v. Giant Yellowknife Mines $L t d .{ }^{5}$ involving a charge under 8. $33(2)$ of the Fisheries Act. The facts of 3 Unreported. 
that case were that Giant Yellowknife Mines, a mining company located at Yellowknife in the Northwest Territories, experienced an overflow of tailings over their tailings disposal dam which ran out onto the ice surface of great Slave Lake. The company entered a plea of guilty to one day, and at the time of sentence, outlined in complete detail the steps which it had taken to clean up the overflow from the ice surface of the lake, as well as the extensive pollution control program which it had underway, which included the expenditure of close to a million dollars for the improvement of the tailings dam. In passing sentence, Magistrate F. G. Smith commented as follows:

Comparing the maximum penalty with the cost of the control program now being
instituted, I am driven to the conclusion that the defendant is not particularly
concerned with the size of the penalty that I am empowered to impose but more with
its corporate image which, if it is seriously damaged, renders it difficult to operate in a
climate of hostile public opinion. The corporation, in the past, has demonstrated its
concern by spending large sums of money on environmental control, particularly dust
control. This is the real deterrent. It knows that it simply cannot carry on by shaving
nickels from this aspect of its operations.

So from the above cases, one can see the principles emerging.

In 1976, the Supreme Court of the Northwest Territories disposed of an appeal by way of trial de novo from both conviction and sentence brought by Canada Tungsten Mining Corporation Limited against a judgment of Deputy Magistrate Eckardt involving three counts under $\mathbf{s}$. 33(2) of the Fisheries Act. The learned magistrate levied fines totalling $\$ 10,000.00$. Both decisions are unreported. On the appeal, the conviction was affirmed, but the sentence was reduced slightly to fines totalling $\$ 8,200.00$. In arriving at an appropriate sentence, Morrow J. said:

As I understand part of appellant counsel's submission, his client moved with alacrity to obtain hay, moss and later an absorbent material, his client commenced burning processes, trenching and finally completely changed the river course. Again here, I am reminded by counsel that the charges refer to specific days and that certainly with respect to Count No. 3 the diversion of the river was perhaps delayed by the governmental people being unable to deliver the formal approval until July 3rd. It is clear that the appellant from the first moment of discovery, and I do not have to review the facts here, acted responsibly and with alacrity. There was no attempt to hide the affair from the authorities. Rather, every effort was made to consult with those responsible for the environment and to act upon their advice. In excess of $\$ 39,000.00$ was spent by the appellant before the problem was under control.

In my view, however, these efforts, laudable as they may be, go more properly to alleviate penalty rather than effect liability. They are all after the event.

... It is important as well, however, to keep in mind the deterrent effect of convictions and resultant consequences in the present type of offence. The magnitude and impersonal nature of present day industrial, mining and similar operations makes it doubly important that the penalty not be so small as to invite breaches as to make it worthwhile to gamble on not being detected: $R$. v. Kenaston Drilling (Arctic) Ltd., (1973) 12 C.C.C. (2d) 383.

In the Yukon Territory, Cyprus Anvil Mining Corporation appeared before Magistrate Dennis R. O'Connor at Whitehorse on November 5, 1975 , in a case similar to the Giant Yellowknife Mines case, charged under s. 33(2) of the Fisheries Act. The facts briefly are that a wall or dike on the defendant company's tailing pond washed out permitting a quantity of deleterious substance to escape into a nearby waterway frequented by fish. In reviewing the facts, the learned magistrate referred to this as being a case involving "the release of an enormous quantity" of toxicity into the waterways. Considering the appropriateness of a fine, the magistrate levied the maximum $\$ 5,000.00$ 


\section{and made the following comments:}

It is suggested that the amount of profit, or the size of the operation of the defendant company should not be considerations with respect to the quantum of fine. Certainly they are not relevant with respect to the defendant company's obligation to be careful. All citizens, corporate and otherwise, rich and poor, have an equal obligation in this respect. However, in determining what fine, if any, would best ensure that the defendant would not permit a repeat occurrence, it seems to me that the size of its operation and its wealth are relevant considerations. I agree that the maximum fine, $\$ 5,000.00$, when compared to the size of the company's operation, seems hardly adequate to induce the company to do something that it is not otherwise motivated to do. But that is not a valid reason for not imposing a fine in that amount.

I must consider as well the deterrence of other companies who are licensed to construct and maintain tailings ponds in the course of their business. As I have said, breaks in the walls surrounding tailings ponds can result in a very substantial escape of deleterious substances into waterways and in most instances, very substantial damage. The fine here ought to point out the serious view that the court will take of any such occurrence. I am satisfied that in this case, for the reasons I have outlined above, that the objectives of sentencing can best be achieved by imposition of the maximum fine. In so doing, I do not feel that to impose the maximum fine with respect to a spillage of this size, and to impose that fine on this defendant, can be described as being harsh or unfair. The defendant company will be fined in the amount of $\$ 5,000.00$ in default distress.

The size of the corporation was also taken into account in a case in the Northwest Territories heard on March 10, 1976, at Hay River, being the case $R$. v. $B \& R$ Construction $L t d .,^{6}$ a decision of Deputy Magistrate Eckhardt. In that case, the accused was a small limited company carrying on business in Hay River with a head office in Hay River. The company entered a plea of guilty to unlawfully conducting a land use operation in a land use management zone without a Land Use Permit, similar to the Kenaston Drilling case. The unauthorized land use operation amounted to the taking of gravel form a gravel pit. The facts showed that there was no ecological damage caused by this operation. Though the maximum fine possible was $\$ 5,000.00$, the learned magistrate imposed a fine of $\$ 650.00$, in the course of which he made the following comments:

In considering a proper and equitable sentence I comprehend that it is incumbent on the court to consider the facts and circumstances of each individual case, the ability of an accused to pay any imposed fine and, of course, other cardinal principles of sentencing including deterrence, protection of the public, and the reformation and the rehabilitation of the offender. In my opinion a court in sentencing, should also be flexible and subject to change as social concepts change.

The public can best be protected by the imposition of sentences that punish the offender, as well as deter the offender and others from committing such an offence again.

The offender in the case at Bar is a small, private, local company that has operated in Hay River and vicinity for some five (5) years or so. I am mindful of the fact that while a maximum fine of $\$ 5,000.00$ might be a mere "drop in the bucket" to a large national conglomerate corporation, nevertheless such a sizable fine might well be the death-knell of a small company such as the accused in the instant case.

In September, 1976, at Whitehorse, Yukon Territory, Cyprus Anvil Mining Corporation again appeared in court, this time before Magistrate E. Horembala, charged on two counts involving offences laid under 8 . 6(1) of the Northern Inland Waters Act. That Act, in order to be consistent with the Fisheries Act and offences under the Territorial Lands Act, provides for maximum fines of $\$ 5,000.00$ per day. The facts show that the charges concern another leakage from the tailings pond into

- Unreported. 
Rose Creek resulting in a high level of cyanide contamination in excess of the limit authorized as a condition in the company's licence to use water. In levying fines totalling $\$ 49,000.00$, the learned magistrate, in reviewing the company's conduct, said:

I find the conduct borders on wilful blindness. The company knew the risks. It had previously been convicted of discharging effluent into these waters as late as November 5, 1975. In that case, too, the safety of the dam itself was brought into question. To say that the company for the first time is reacting to an environmental emergency would, of course, not be true. It was anxious to start up operations, and did 80 negligently. It continued to operate the mill at all costs up to and until February 24 when ordered to shut down or face an injunction. The majority of expense incurred by the company was after it became apparent that the safety of the dam was in question, that the effluent would have to be discharged and the problem now had assumed major proportions. Had some expenditures been incurred by the company, however slight, prior to that date, then it would have been evidence of the company's good intentions. I find the total conduct of the company in that crucial period given its previous experience to fall within the "worst case" category. I think the words of the court in Regina v. Kenaston Drilling (Arctic) Ltd. (1973) 12 C.C.C. (2d) 383, are appropriate in this case. The magnitude and the personal nature of present day industrial mining in similar operations makes it doubly important that the penalty not be so small as to invite breaches as to make it worthwhile to gamble on it not being detected.

By way of summary, the principles that appear from the foregoing cases bearing on the matter of sentence would appear to be as follows:

(1) The test to apply in approaching the matter of sentencing should be less a concern of what the damage was but more a concern of what the damage might have been.

(2) Fines should not be so nominal as to invite corporations to take a gamble as to detection.

(3) The deterrent should be stressed in this type of offence.

(4) Yet where ecological damage has not occurred or is minimal or where the company moves quickly, openly alerting authorities, and spends large sums of money on clean-up, then the fines, though not nominal, would not justify the maximum.

(5) The size of the company's operations, whether it is large or small, and its wealth, or lack of same, are relevant considerations.

(6) If the company's conduct amounts to wilful blindness such that it may be said to fall within the "worst case" category, then the maximum fine is justified.

\section{Defences}

\section{(a) Under the Fisheries Act}

The relevant section under the Fisheries Act that creates the offence is s. $33(2)$, which reads as follows:

s. 33(2)-Subject to subsection (4), no person shall deposit or permit the deposit of a deleterious substance of any type in water frequented by fish or in any place or under any conditions where such deleterious substance or any other deleterious substance that results from the deposit of such deleterious substance may enter any such water.

The elements of the offence are obvious from the foregoing section and from the definition of "deleterious substance" and "water frequented by fish" found in the Act. Assuming the elements set out in s. 33(2) are proven, then the defence must rely upon s. $33(8)$, which provides:

In a prosecution for an offence under this section or Section 33.4, it is sufficient proof of the offence to establish that it was committed by an employee or agent of the accused whether or not the employee or agent is identified or has been prosecuted for 
the offence, unless the accused establishes that the offence was committed without his knowledge or consent and that he exercised all due diligence to prevent its com. mission. (emphasis added)

The question here is how far must a defendant company go to establish that the offence was committed without its knowledge or consent and that it exercised all due diligence to prevent its commission. In the Elf case, the learned magistrate rejected that defence because of the lack of continuous supervision of the fuel storage site before the break was noticed. In the Canada Tungsten case, Morrow J., in dealing with this defence said:

It is admitted that the appellant did not consent to this escape. This is quite true in the sense that the appellant did not willingly wish to have such a leakage take place, did not willingly open a valve or permit some similar event to take place.

If consent or the lack of consent in the above context were the full test of liability, then the appellant would probably have a full defence. But surely "consent" as used here must be read in proper context. Surely it is related to the vicarious aspect of liability, and is intended as a relaxation of the strict liability which would otherwise result from the effect of sec. 33(2) alone where before the passing of sec. 33(8) acts of employees could be taken to bind an employer in the strictest sense.

Oil spills, leakages or seepage of the type found in the present case are all accidental. They are probably never intended: $R$. v. Power Tank Lines Limited, (unreported Prov. Judge J. D. Ord, Ontario Prov. Ct. 28 Jan. 1975). Certainly the appellant did not consent to the deposit of the oil in the ground from whence it did enter the water in the sense of willingly agreeing or hoping for such result. But to avoid liability the appellant must couple lack of consent with a behaviour or consciousness which in effect shows it was not blind to the consequences of the possibility as well as the consequent danger of a leakage such as is found in the present case.

The general approach to the problem is beautifully expressed in Sweet v. Parsley, (1970) A.C. 132 where Lord Diplock states at page 163:

Where penal provisions are of general application to the conduct of ordinary citizens in the course of their everyday life, the presumption is that the standard of care required of them in informing themselves of facts which would make their conduct unlawful, is that of rhe familiar common law duty of care. But where the subject matter of a statute is the regulation of a particular activity involving potential danger to public health, safety or morals, in which citizens have a choice as to whether they participate or not, the Court may feel driven to infer an intention of Parliament to impose, by penal sentences, a higher duty of care on those who choose to participate and to place on them an obligation to take whatever measures may be necessary to prevent the prohibited act, without regard to those considerations of cost or business practicability which play a part in the determination of what would be required of them in order to fulfil the ordinary common law duty of care.

I must now see whether the appellant, on the agreed facts, can come within the latter portion of sec. $33(8)$ namely: 'that he exercised all due diligence to prevent its commission.'

I cannot read the wording of sec. 33(8) except to require 'due care and diligence' to refer to preventing the leak not to correcting the leak or reducing the damage. It is quite true, as was argued, that to prevent the leak in the present case, to set up inspections to look for weaknesses in the installations such as are found at appellant's plant may be difficult. The fact of the matter is that no such tests appear to have ever been made since the plant was erected, and certainly no routine ever laid down for opening the packing around the offending pipes to see if erosion was taking place.

The appellant's plant is situate in a mountainous terrain, where extremes of climate are common, and where its very remoteness makes it more necessary perhaps to show care. No matter what, the primary responsibility for proper installation, repair, and maintenance as well as inspection must always rest with an appellant as is found here. There is no basis in fact or in law wherein I can find even a small effort which could be termed due 'diligence to prevent'.

In the first Cyprus Anvil Mining case referred to herein, counsel for the company argued unsuccessfully that since no complaint had been 
made to the company, prior to the wash-out, by government inspectors regarding weakness or fault in the retaining walls, the company had shown the proper degree of diligence. The response of the learned magistrate was that "the primary responsibility for the proper design, construction, inspection and maintenance of the retaining wall rested with the defendant company" not with government inspectors. So it would appear that even if government agencies were to approve and inspect a company's tailing pond and its design, such approval and inspection would be no defence to a company.

Therefore, to establish the defence of due diligence, not only must the offence have been committed without the knowledge or consent of the company, but prior to the occurrence the company must be able to show competent design and installation and a clear program of inspection, repair and maintenance. The company has that primary responsibility, no one else, not even the government.

\section{(b) Under the Land Use Regulations}

In discussing these Regulations, one must appreciate that we are examining those currently in force. ${ }^{7} \mathrm{~A}$ revision has been proposed and is expected to be brought into force by Order-in-Council within the foreseeable future. However, what is hereinafter stated will likely not be affected by the new Regulations.

In this paper, only two defences will be discussed, one of which has already been advanced before a court and rejected; and the other which has not yet been advanced to the author's knowledge.

\section{(i) Extension of expired permit}

In the Gulf Oil case a preliminary motion was made before Morrow J. sitting as a magistrate to quash the information which charged the defendant company with a breach of a condition of Land Use Permit which was imposed, not under the original permit, by way of an extension of the permit. The extension, however, was granted after the original permit had expired. The argument made by the company was that an expired permit could not be extended, that for an extension to be valid, it would have to be done before the permit expired, hence any charge based upon such a condition is a nullity as it failed to disclose any offence. Two old cases were relied upon by the company: The Queen v. The Licensing Justices of Crewkerne, ${ }^{8}$ and Brooke v. Clarke et al..9 Both these cases were distinguished by Morrow J. who rejected the motion and held as follows:

It seems to me that so long as the extension does not go beyond one year there is no other restriction on the engineer as to time, that it is implicit in the language of the Regulations that extensions may be given at any time, retroactively if necessary. I feel fortified in this opinion to some extent by the wording found in 8 . 21(4) where reference is made to the period of the permit: 'shall be based on the estimated dates of commencement and completion' and this surely suggests the need for flexibility.

Counsel for the applicant further submits that the legislation does not permit granting an extension even if the extension was granted before the expiration of the permit, that to this extent 8 . 21(5) of the Regulations is ultra vires.

' See supra, n. 1.

(1883) 1 Q.B.D. 85.

- 1 B. \& Ald. 396, 106 E.R. 146. 
In view I take of the legislation 8. 3.2(b) of the Territorial Lands Act gives legislative authority for making Regulations respecting the issue of permits. In stating that these Regulations may include 'terms and conditions', I fail to see how the power to extend cannot be considered as being just as reasonable a type of term or condition as any of the other myriad of contingencies that those required to administer the legislation must anticipate in drafting the Regulations. (emphasis added)

(ii) Delagatus non potest delegare

This well-known defence has not, to the author's knowledge, been argued respecting the ultra vires of the Land Use Regulations, nor with respect to the ultra vires of certain of the conditions imposed in some of the Land Use Permits.

To understand the argument, we must start with the Territorial Lands Act, then go to the Regulations and then take a hypothetical condition which has appeared in previous Land Use Permits.

The relevant words of the relevant sections of the Act are reproduced as follows:

3.2 The Governor in Council may . . . make regulations respecting . . .

(b) the issue of permits for the use of the surface of land in a land management zone, the terms and conditions of such permits and the fees therefor.

3.3 (1) Every person who ...

(b) fails to comply with any term or condition of a permit . . . is guilty of an offence...

As may be seen from the foregoing, the Act grants unto the Governor in Council the power to make regulations respecting the terms and conditions of permits. Then, when we examine the Territorial Land Use Regulations, we see the appearance of the "engineer" who is given authority under s. 20 and 21 of said Regulations as follows:

20. (1) The engineer shall ...

(a) issue a permit subject to any conditions he may include therein pursuant to 88. 21(1), or

(b) refuse to issue a permit, ... or ...

21. (1) The engineer may include in any land use permit conditions respecting ... (a) ... (k) ...

Thus, the engineer is not only given discretionary power to decide whether a permit will issue or not, but the Regulations further empower him to set the conditions of the permit. Breach of these conditions will render the operator liable to prosecution for an offence under the Act. The engineer, we submit, is therefore legislating the offence.

By 8. 33 of the Regulations, the engineer may cancel the permit for a breach of its conditions. This would seem to be a purely administrative task which can be delegated to an administrative official without express authority from Parliament to do so. But if the engineer is setting the conditions as well, instead of the Governor in Council, he is legislating an offence at law. If it was the intention of Parliament that such a legislative function be sub-delegated, it should have expressly stated such intention.

If we then take a hypothetic condition from a Land Use Permit and give it a condition number 20 as follows: 
20. The location and preparation of all sumps and pits shall be such as to avoid long-term erosion and seepage problems to the satisfaction of the Land Use inspector. (emphasis added)

What has then occurred is a further delegation by the engineer to his inspector.

But starting at the beginning, first there is a delegation from Parliament to the Governor in Council (s. 3 of the Act), then there is a delegation from the Governor in Council to the engineer (ss. $20 \& 21$ of the Regulations), and finally there is a delegation from the engineer to the land use inspector (condition 20). The issue is what delegation, if any, is authorized?

It is the author's suggestion that, in the absence of statutory authority, discretionary power vested in a subordinate body such as either the Governor in Council or the engineer, cannot in turn be sub-delegated by either of them. As support for this view, we cite the cases: Vic Restaurant Inc. v. City of Montreal ${ }^{10}$ and Bridge v. The Queen ex rel. Skalinski."1

Based on the foregoing, there is little doubt that the delegation from the engineer to the land use inspector is ultra vires, but as well, it is submitted that what is missing is a provision in the Act authorizing the Governor in Council to confer on the engineer the right to decide what conditions may be placed on any permit.

Should a company succeed on the basis of the foregoing argument, the implications are obvious. At the very least, certain conditions of land use permits would be ultra vires, if not all of the permits in their entirety, leaving no regulations as to the use of the surface of the land.

-DAVID SEARLE, Q.C.*

to (1959) 17 D.L.R. (2d) 81, 94.

" (1953), D.L.R. 305.

* B.A., LL.B. (Alta.), of the firm of Searle Sigler, Yellowknife, N.W.T.

\section{SOME THOUGHTS ON THE DRAFTING OF CONDITIONS IN CONTRACTS FOR THE SALE OF LAND}

Contracts for the sale of land are frequently, if not usually, conditional in nature. Conditional contracts are contracts in which the ultimate promise of performance on one or both sides is made to depend upon the happening or non-happening, or upon the existence or nonexistence of some specific event or state of affairs. Most frequently conditions in contracts for the sale of land relate to the obtaining of finance by the purchaser or the obtaining of some necessary approval for a development of the property which the purchaser has in mind and for which reason he is buying. They may, however, be concerned with a variety of other matters and may and do take many different forms. For example, some contracts are made simply "subject to the purchaser obtaining satisfactory finance" while others may specify the nature of the finance to be obtained in considerable detail, or may set out the steps for obtaining planning approval or the like and lay down a timetable for 